\title{
KINERJA OPERASIONAL PELABUHAN PERIKANAN DI PERAIRAN TELUK SEMANGKA KABUPATEN TANGGAMUS LAMPUNG
}

\author{
The Operational Performance of Fishing Ports in Semangka Bay, Tanggamus Regency, Lampung \\ Oleh: \\ Khoerul Fatoni ${ }^{1}$, Iin Solihin²* dan Retno Muninggar ${ }^{3}$ \\ 1Program Studi Teknologi Perikanan Laut, Pascasarjana IPB, khoerulfatoni@apps.ipb.ac.id \\ 2Departemen Pemanfaatan Sumberdaya Perikanan, FPIK IPB, iin_solihin@apps.ipb.ac.id \\ ${ }^{3}$ Departemen Pemanfaatan Sumberdaya Perikanan, FPIK IPB, muninggar@apps.ipb.ac.id \\ * Korespondensi: iin_solihin@apps.ipb.ac.id
}

Diterima: 6 Juli 2021; Disetujui: 11 Desember 2021

\begin{abstract}
The Semangka Bay in Tanggamus Regency of Lampung Province is a potential area for capture fisheries activities. As the primary basis for the capture fisheries sector, the fishing port can increase regional economic growth. The condition of the fishing port in the Tanggamus Regency has not been optimal in supporting the regional economic improvement. The transfer of authority for fishing ports from the Tanggamus District Government to the Lampung Provincial Government makes efforts to develop fishing ports through the Regional Fisheries Port Master Plan (RFPMP) that need to be revised. The preparation of the RFPMP requires information related to the operational conditions of fishing ports. Still, until now, the Lampung Provincial government has not yet received information on the overall operational level of fishing ports in the Tanggamus Regency. This study aims to describe the operating conditions of the fishing port in the Tanggamus Regency. The research method is descriptive with two stages. The first assessment of the operational performance of fishing ports. Second, gap assessment of fishing ports. The result showed that the average value of fishing ports' operational performance is $26 \%$, and the average gap value is $74 \%$. The operating condition of the fishing ports in the Tanggamus Regency is classified as inferior. Fishing port facilities have the lowest performance and the highest gap. Improvements to the fishing ports facilities in Tanggamus Regency are needed through local governments' procurement and proper maintenance.
\end{abstract}

Keywords: fishing port, gap, operational, performance, Tanggamus Regency.

\begin{abstract}
ABSTRAK
Teluk Semangka Kabupaten Tanggamus, Lampung merupakan wilayah yang potensial untuk kegiatan penangkapan ikan. Pelabuhan perikanan sebagai basis utama pada sektor perikanan tangkap berpotensi untuk meningkatkan pertumbuhan ekonomi wilayah. Kondisi pelabuhan perikanan di Kabupaten Tanggamus belum optimal dalam mendukung peningkatan ekonomi wilayah. Adanya pengalihan wewenang pelabuhan perikanan dari pemerintah Kabupaten Tanggamus ke pemerintah Provinsi Lampung membuat upaya pengembangan pelabuhan perikanan melalui Rencana Induk Pelabuhan Perikanan Daerah (RIPPD) perlu direvisi. Penyusunan RIPPD memerlukan informasi terkait kondisi operasional pelabuhan perikanan, namun sampai saat ini pemerintah Provinsi Lampung belum mengetahui informasi tingkat operasional pelabuhan perikanan secara keseluruhan di Kabupaten Tanggamus. Penelitian ini bertujuan untuk menilai kinerja operasional pelabuhan perikanan di Kabupaten Tanggamus. Metode penelitian yang digunakan adalah deskriptif dengan dua tahapan, pertama menilai kinerja operasional pelabuhan perikanan,
\end{abstract}


kedua menilai kesenjangan pelabuhan perikanan. Hasil penelitian menunjukkan bahwa rata-rata kinerja operasional pelabuhan perikanan di Kabupaten Tanggamus adalah $26 \%$ dengan kesenjangan sebesar $74 \%$. Kondisi operasional pelabuhan perikanan di Kabupaten Tanggamus tergolong kurang baik. Kriteria fasilitas pelabuhan perikanan menjadi kriteria dengan kinerja terendah dan kesenjangan tertinggi. Upaya pengembangan pelabuhan perikanan perlu dilakukan melalui penyediaan dan perbaikan fasilitas pelabuhan perikanan oleh pemerintah daerah.

Kata kunci: pelabuhan perikanan, kesenjangan, operasional, kinerja, Kabupaten Tanggamus.

\section{PENDAHULUAN}

Perairan Teluk Semangka Kabupaten Tanggamus Provinsi Lampung merupakan wilayah yang potensial untuk pengembangan kegiatan perikanan tangkap. Letak perairan Teluk Semangka yang termasuk ke dalam Wilayah Pengelolaan Perikanan (WPP) 572 memiliki potensi besar dari sisi sumberdaya ikan. Potensi sumberdaya ikan di WPP 572 mencapai 1,23 juta ton/tahun (Suman et al. 2016). Potensi perairan yang besar di Teluk Semangka didukung dengan tersedianya prasarana pelabuhan perikanan. Pelabuhan perikanan berperan penting dalam pengembangan sektor perikanan tangkap (Lubis 2011).

Pelabuhan perikanan berperan sebagai prasarana penghubung antara kegiatan penangkapan (produksi) dan pemasaran (distribusi) ikan hasil tangkapan (Solihin et al. 2011). Peranan tersebut menjadikan pelabuhan perikanan sebagai pusat kegiatan ekonomi bagi masyarakat pesisir khususnya bagi nelayan di Teluk Semangka. Sebagai pusat perekonomian masyarakat pesisir pelabuhan perikanan diharapkan mampu menyediakan lapangan pekerjaan (Pramoda et al. 2013), memenuhi kebutuhan konsumsi masyarakat (Susanto et al. 2020), memicu peningkatan usaha (Kristiyanti et al. 2020), dan meningkatkan pembangunan infrastruktur wilayah (Nurhalimah et al. 2017). Dengan demikian, pelabuhan perikanan berpotensi meningkatkan perekonomian di suatu wilayah dan menambah Pendapatan Asli Daerah (PAD).

Pelabuhan perikanan di Kabupaten Tanggamus berjumlah tujuh unit yaitu Pelabuhan Perikanan (PPI) Guring, PPI Karanganyar, PPI Tegineneng, PPI Badak, PPI Penyandingan dan Pelabuhan Perikanan Pantai (PPP) Kota Agung. Berdasarkan hasil wawancara awal kepada pemerintah daerah yaitu Dinas Kelautan dan Perikanan (DKP) Provinsi Lampung dan DKP Kabupaten Tanggamus pada Januari 2020 diketahui bahwa, kondisi pelabuhan perikanan di Teluk Semangka Kabupaten Tanggamus belum beroperasi secara optimal. Terbatasnya fasilitas dan infrastruktur pelabuhan perikanan serta tingkat operasional pelabuhan perikanan yang rendah diduga telah mengakibatkan tiga pelabuhan perikanan yang tidak operasional yaitu PPI Guring, PPI Karanganyar, PPI Putih Doh. Tidak operasionalnya pelabuhan perikanan mengakibatkan pemerintah daerah kehilangan sumber pendapatan dari pelabuhan perikanan (Sari et al. 2018), nelayan tidak mendapatkan pelayanan dari pelabuhan perikanan (Rizayani et al. 2016), dan masyarakat sekitar juga kehilangan lapangan pekerjaan dan peluang membangun usaha (Kristiyanti et al. 2020). Mengingat pentingnya peran pelabuhan perikanan, maka upaya pengembangan pelabuhan perikanan di Kabupaten Tanggamus perlu dilakukan.

Berdasarkan UU Nomor 23 tahun 2014 tentang pemerintahan daerah kewenangan pengembangan pelabuhan perikanan berada di bawah pemerintah Provinsi (KEMENSETNEG, 2014). Saat penelitian dilakukan, 6 (enam) PPI di Kabupaten Tanggamus masih dalam proses penyerahan personel, pendanaan, sarana dan prasarana serta dokumen (P3D) dari pemerintah Kabupaten Tanggamus ke pemerintah Provinsi Lampung. Pengalihan kewenangan tersebut tentu perlu ditindaklanjuti oleh pemerintah provinsi dengan merevisi Rencana Induk Pelabuhan Perikanan Daerah (RIPPD), namun kondisi teknis dan operasional pelabuhan perikanan secara keseluruhan di Kabupaten Tanggamus belum diketahui oleh pemerintah Provinsi Lampung, sehingga upaya pengembangan pelabuhan melalui penyusunan RIPPD menjadi terhambat. Disisi lain, dana yang terbatas membuat upaya pengembangan pelabuhan perikanan tidak dapat dilakukan secara cepat dan menyeluruh. Ditambah lagi dengan banyaknya jumlah pelabuhan perikanan di Kabupaten Tanggamus membuat dana yang dibutuhkan oleh pemerintah provinsi menjadi semakin besar, sehingga upaya pengembangan sam- 
pai saat ini belum terealisasi. Apabila hal ini dibiarkan maka tujuan pemerintah daerah untuk meningkatkan ekonomi wilayah di Kabupaten Tanggamus menjadi sulit diwujudkan.

Berdasarkan hasil Focus Group Discussion tentang Rencana Induk Pelabuhan Perikanan Nasional di Provinsi Lampung pada September 2020, diketahui bahwa jumlah pelabuhan perikanan yang akan dikembangkan pada zona WPP 572 di Provinsi Lampung saat penelitian dilakukan berjumlah 18 pelabuhan perikanan dengan rincian 2 unit PPP dan 16 unit PPI. Berdasarkan kapasitas minimal operasional untuk 18 pelabuhan perikanan tersebut diperoleh jumlah tangkapan sebesar 15.330 ton/tahun. Jumlah tersebut telah melebihi kuota sumber daya ikan pada zona WPP 572 yang diperuntukkan untuk Provinsi Lampung yang berjumlah 12.417 ton/tahun (DJPT, 2020). Di sisi lain, adanya dugaan bahwa 3 unit pelabuhan perikanan di Kabupaten Tanggamus sudah tidak operasional sebagaimana telah dijelaskan sebelumnya, maka pihak DKP Provinsi Lampung memutuskan untuk mengurangi jumlah pelabuhan perikanan dan memfokuskan pengembangan pada pelabuhan perikanan yang sudah operasional. Hal ini didukung juga dengan Peraturan Pemerintah Nomor 27 Tahun 2021 tentang Penyelenggaraan Bidang Kelautan dan Perikanan yang menyebutkan bahwa upaya pengembangan pelabuhan perikanan dapat dilakukan pada pelabuhan perikanan yang telah beroperasi dan telah ditentukan kelasnya (KEMENSETNEG 2021). Oleh karena itu, penilaian terhadap tingkat kinerja operasional pelabuhan perikanan di Kabupaten Tanggamus sangat penting diketahui oleh pemerintah daerah Provinsi Lampung. Dengan diketahuinya tingkat kinerja operasional pelabuhan perikanan, maka pengembangan pelabuhan perikanan yang akan dilakukan oleh pemerintah Provinsi Lampung di Kabupaten Tanggamus dapat dilakukan secara tepat karena berlandaskan kondisi eksisting pelabuhan perikanan. Jika kinerja operasional pelabuhan perikanan tidak diketahui maka rencana pengembangan pelabuhan perikanan di Kabupaten Tanggamus menjadi terhambat. Apabila kondisi ini dibiarkan maka dapat mengakibatkan penurunan kegiatan operasional pelabuhan perikanan. Dengan demikian manfaat pelabuhan perikanan menjadi kurang dirasakan oleh para nelayan, masyarakat sekitar pelabuhan bahkan pemerintah daerah.

Dalam rangka membantu pemerintah daerah Provinsi Lampung untuk memperoleh informasi kinerja operasional pelabuhan perikanan di Kabupaten Tanggamus, maka penelitian dengan tujuan menilai tingkat operasional pelabuhan perikanan di Kabupaten Tanggamus perlu dilakukan. Informasi tingkat operasional diharapkan dapat digunakan oleh pihak pemerintah daerah Provinsi Lampung sebagai bahan pertimbangan dalam memilih pelabuhan perikanan yang akan dikembangkan dan menyusun upaya pengembangan pelabuhan perikanan di Kabupaten Tanggamus melalui RIPPD.

\section{METODE}

Penelitian dilakukan pada bulan Desember 2020-Maret 2021 di tujuh pelabuhan perikanan di Perairan Teluk Semangka Kabupaten Tanggamus, Provinsi Lampung. Metode penelitian yang digunakan dalam pencapaian tujuan penelitian adalah metode penelitian deskriptif. Informasi tingkat operasional pelabuhan perikanan dapat diperoleh melalui dua tahapan. Tahap pertama menilai kondisi operasional pelabuhan perikanan di Kabupaten Tanggamus berdasarkan indikator penilaian standar pelabuhan perikanan yang telah disusun berdasarkan Keputusan Direktur Jenderal Perikanan Tangkap (DJPT) Nomor 20 Tahun 2015 tentang Pedoman Evaluasi Kinerja Pelabuhan Perikanan, dan kondisi standar pelabuhan perikanan yang diharapkan oleh pemerintah daerah. Pengumpulan data tahap pertama dilakukan melalui observasi lapang, wawancara kepada pihak pengelola pelabuhan perikanan melalui kuesioner, dan pengumpulan data sekunder. Analisis data yang digunakan pada tahap pertama adalah analisis kinerja pelabuhan perikanan. Tahap kedua mengukur kesenjangan antara kondisi operasional dengan kondisi standar pelabuhan perikanan. Pengukuran dilakukan dengan menghitung selisih antara nilai maksimum standar pelabuhan perikanan dengan nilai kinerja pelabuhan perikanan yang telah diperoleh pada tahap pertama. Hasil analisis disajikan dalam bentuk tabel dan diagram kemudian dijelaskan secara deskriptif.

Jenis data yang dikumpulkan yaitu kondisi operasional, fasilitas, dan infrastruktur pendukung di tujuh pelabuhan perikanan di Kabupaten Tanggamus. Sumber data diperoleh dari hasil studi literatur, pengumpulan data sekunder, observasi dan wawancara. Wawancara dilakukan kepada responden yang terdiri dari 1 orang dari pihak DKP Provinsi Lampung, 1 orang dari pihak DKP Kabupaten Tanggamus, dan 7 orang Pengelola Pelabuhan Perikanan. Penentuan 
responden dilakukan secara purposive sampling, dengan kriteria memahami operasional pelabuhan perikanan dan terlibat dalam

pengelolaan pelabuhan perikanan. Berikut disajikan kriteria standar pelabuhan perikanan Kabupaten Tanggamus pada Tabel 1.

Tabel 1 Kriteria standar pelabuhan perikanan di Kabupaten Tanggamus

\begin{tabular}{|c|c|c|c|}
\hline Kriteria & Bobot & Pelabuhan Perikanan Pantai (PPP) & Pangkalan Pendaratan Ikan (PPI) \\
\hline 1. Operasional & 45 & Skor maksimum $=4$ & Skor maksimum $=4$ \\
\hline Pelayanan tambat labuh & 3 & Melayani kapal $\leq 30 \mathrm{GT}$ & Melayani kapal $\leq 10 \mathrm{GT}$ \\
\hline Produksi ikan hasil tangkapan & 3 & $\geq 5$ ton/hari & $\geq 2$ ton/hari \\
\hline Kunjungan kapal & 3 & $\geq 50$ unit/bulan & $\geq 20$ unit/bulan \\
\hline Jumlah kapal & 3 & 500 unit & 200 unit \\
\hline Kegiatan pelelangan ikan & 3 & Seluruh ikan dilelang & Seluruh ikan dilelang \\
\hline Penyediaan air bersih & 3 & Sesuai kebutuhan $100 \%$ & Sesuai kebutuhan $100 \%$ \\
\hline Penyediaan es & 3 & Sesuai kebutuhan $100 \%$ & Sesuai kebutuhan $100 \%$ \\
\hline Penyediaan BBM & 3 & Sesuai kebutuhan $100 \%$ & Sesuai kebutuhan $100 \%$ \\
\hline Kegiatan administrasi pelabuhan & 3 & Berjalan dengan sangat baik & Berjalan dengan sangat baik \\
\hline Keamanan dan kebersihan & 3 & Berjalan dengan sangat baik & Berjalan dengan sangat baik \\
\hline Kegiatan perbaikan kapal & 3 & Berjalan dengan sangat baik & Berjalan dengan sangat baik \\
\hline Industri pengolahan ikan & 3 & $\geq 10$ unit & $\geq 5$ unit \\
\hline Kegiatan penyewaan lapak pedagang & 3 & Pendapatan sewa $100 \%$ & Pendapatan sewa $100 \%$ \\
\hline Penyerapan tenaga kerja & 3 & $\geq 300$ orang & $\geq 150$ orang \\
\hline $\begin{array}{l}\text { Ketersediaan SDM pengelola } \\
\text { pelabuhan perikanan }\end{array}$ & 3 & Tersedia dengan sangat lengkap & Tersedia dengan sangat lengkap \\
\hline 2. Fasilitas & 35 & & \\
\hline 2a. Fasilitas pokok & 11 & & \\
\hline Lahan & 2 & $\geq 5$ ha & $\geq 2$ ha \\
\hline $\begin{array}{l}\text { Jalan komplek pelabuhan dan } \\
\text { drainase }\end{array}$ & 2 & Tersedia dengan kondisi sangat baik & Tersedia dengan kondisi sangat baik \\
\hline Breakwater & 1 & Tersedia dengan kondisi sangat baik & Tersedia dengan kondisi sangat baik \\
\hline Panjang demaga & 2 & $\geq 100 \mathrm{~m}$ & $\geq 50 \mathrm{~m}$ \\
\hline Kapasitas kolam pelabuhan & 2 & $\geq 300 \mathrm{GT}$ & $\geq 75 \mathrm{GT}$ \\
\hline Kedalaman kolam pelabuhan & 2 & $\geq 2 \mathrm{~m}$ & $\geq 2 \mathrm{~m}$ \\
\hline 2b. Fasilitas fungsional & 17 & & \\
\hline Tempat pelelangan ikan (TPI) & 2 & Tersedia dengan kondisi sangat baik & Tersedia dengan kondisi sangat baik \\
\hline $\begin{array}{l}\text { Peralatan pemasaran (basket, } \\
\text { sterofoam, box fiber) }\end{array}$ & 1 & Tersedia dengan kondisi sangat baik & Tersedia dengan kondisi sangat baik \\
\hline Lapak pedagang & 1 & Tersedia dengan kondisi sangat baik & Tersedia dengan kondisi sangat baik \\
\hline Kantor TPI & 2 & Tersedia dengan kondisi sangat baik & Tersedia dengan kondisi sangat baik \\
\hline Kantor pelabuhan & 2 & Tersedia dengan kondisi sangat baik & Tersedia dengan kondisi sangat baik \\
\hline Docking & 1 & Tersedia dengan kondisi sangat baik & Tersedia lahan untuk docking \\
\hline Bengkel & 1 & Tersedia dengan kondisi sangat baik & Tersedia lahan untuk bengkel \\
\hline Tempat penampungan es & 1 & Tersedia dengan kondisi sangat baik & Tersedia lahan untuk pabrik es \\
\hline $\begin{array}{l}\text { Stastiun pengisian bahan bakar } \\
\text { nelayan (SPBN) }\end{array}$ & 1 & Tersedia dengan kondisi sangat baik & $\begin{array}{l}\text { Tersedianya SPBM mini yang } \\
\text { memadai }\end{array}$ \\
\hline Sumber tenaga listrik & 2 & Tersedia dengan kondisi sangat baik & Tersedia dengan kondisi sangat baik \\
\hline Sumber air bersih & 2 & Tersedia dengan kondisi sangat baik & Tersedia dengan kondisi sangat baik \\
\hline $\begin{array}{l}\text { Lahan penjemuran dan perbaikan } \\
\text { alat tangkap }\end{array}$ & 1 & Tersedia dengan kondisi sangat baik & Tersedia dengan kondisi sangat baik \\
\hline 2c. Fasilitas penunjang & 7 & & \\
\hline Gerbang masuk pelabuhan & 1 & Tersedia dengan kondisi sangat baik & Tersedia dengan kondisi sangat baik \\
\hline Pos jaga & 2 & Tersedia dengan kondisi sangat baik & Tersedia dengan kondisi sangat baik \\
\hline Mandi, cuci, kakus (MCK) & 2 & Tersedia dengan kondisi sangat baik & Tersedia dengan kondisi sangat baik \\
\hline Kantin & 1 & Tersedia dengan kondisi sangat baik & Tersedia dengan kondisi sangat baik \\
\hline Lahan parkir & 1 & Tersedia dengan kondisi sangat baik & Tersedia dengan kondisi sangat baik \\
\hline 3. Infrastruktur pendukung & 20 & & \\
\hline Jaringan telekomunikasi & 10 & Tersedia dengan kondisi sangat baik & Tersedia dengan kondisi sangat baik \\
\hline Akses jalan & 10 & Tersedia dengan kondisi sangat baik & Tersedia dengan kondisi sangat baik \\
\hline
\end{tabular}

Tabel 2 Nilai kinerja pelabuhan perikanan

\begin{tabular}{ll}
\hline Nilai Kinerja & Predikat \\
\hline $0 \%-20 \%$ & Sangat kurang \\
$>20 \%-40 \%$ & Kurang \\
$>40 \%-60 \%$ & Cukup \\
$>60 \%-80 \%$ & Baik \\
$>80 \%-100 \%$ & Sangat baik \\
\hline Sumber: Ngamel
\end{tabular}

Sumber: Ngamel et al. (2017) diolah kembali 
Perhitungan nilai kinerja pelabuhan perikanan dilakukan dengan menggunakan formulasi penilaian sebagai berikut:

$N K i=\frac{S k i \times B k i}{S m a x k i}$

dengan:

NKi : Nilai kriteria ke-i (NKOi, NFi, dan NIFI)

Ski : Jumlah skor kriteria ke-i

$B k i$ : Jumlah bobot kriteria ke-i

Smax ki : Jumlah skor maksimum kriteria ke-i

$N K P P i=\frac{N K O i+N F i+N I F i}{N M A X} \times 100 \%$

dengan:

$\mathrm{NKKPi}$ : Nilai kinerja pelabuhan perikanan kei

NKOi : Nilai kinerja operasional pelabuhan perikanan ke-i

$\mathrm{NFi}$ : Nilai fasilitas pelabuhan perikanan ke-i

NIFi : Nilai infrastruktur pendukung pelabuhan perikanan ke-i

Nmax : Nilai maksimum seluruh kriteria (100)

Pengukuran kesenjangan dilakukan dengan mengukur kesenjangan antara kondisi aktual dengan kondisi yang diharapkan (standar) (Siswoyo dan Kurniawan 2014). Pengukuran kesenjangan pelabuhan perikanan dilakukan adalah menghitung selisih nilai antara kondisi standar yang diharapkan oleh pemerintah daerah dengan kondisi operasional pelabuhan perikanan di Kabupaten Tanggamus. Semakin rendah nilai kesenjangan menunjukkan bahwa kondisi operasional pelabuhan perikanan semakin mendekati kondisi standar yang diharapkan oleh pemerintah daerah, dan sebaliknya semakin tinggi nilai kesenjangan maka kondisi operasional pelabuhan perikanan dinilai masih jauh dari standar yang diharapkan pemerintah daerah (Wijayanto et al. 2010)

\section{HASIL}

Hasil perhitungan nilai kinerja pelabuhan perikanan pada Tabel 3, menunjukkan bahwa nilai kinerja operasional (7) tujuh pelabuhan perikanan di Kabupaten Tanggamus pada tahun 2020 berkisar antara $9 \%-65 \%$, dengan rata-rata sebesar $27 \%$. Secara umum kinerja pelabuhan perikanan di Kabupaten Tanggamus dinilai kurang baik. Pelabuhan perikanan dengan nilai kinerja tertinggi adalah PPP Kota Agung dengan nilai $65 \%$, sedangkan nilai kinerja operasional terendah dialami oleh PPI Guring dengan nilai $9 \%$.

Kinerja operasional yang baik di PPP Kota Agung didukung oleh aktivitas operasional yang berjalan cukup baik dengan tingkat pencapaian sebesar $58 \%$. Jumlah produksi ikan yang didaratkan tahun 2020 yang mencapai 393,03 ton /tahun atau 1,1 ton/hari, jumlah kapal sebanyak 181 unit dengan frekuensi kunjungan sebanyak 3.329 unit/tahun atau 9 unit/hari (UPTD PPP Kota Agung 2020). Fasilitas di PPP Kota Agung dinilai cukup baik dengan tingkat pencapaian sebesar $50 \%$ yang ditandai dengan tersedianya fasilitas pokok, fungsional, dan penunjang yang cukup lengkap dan memadai. Banyaknya jumlah produksi, armada, dan frekuensi kunjungan kapal serta ketersediaan fasilitas pelabuhan perikanan berpengaruh positif terhadap kinerja operasional pelabuhan perikanan (Nugroho et al. 2012; Ngamel et al. 2017). Infrastruktur pendukung dinilai sangat baik dengan nilai pencapaian $100 \%$. Lokasi PPP Kota Agung berada di lbukota Kabupaten Tanggamus, sehingga ketersediaan infrastruktur pendukung seperti sumber listrik, jaringan komunikasi serta akses jalan yang sudah memadai.

Pelabuhan perikanan dengan kinerja sangat kurang adalah PPI Guring, PPI Karanganyar, dan PPI Putih Doh. Berdasarkan hasil wawancara dengan pengelola pelabuhan perikanan diketahui bahwa ketiga pelabuhan tersebut sudah tidak beroperasi sejak tahun 2008. Tidak operasionalnya pelabuhan perikanan diakibatkan oleh nelayan yang tidak melakukan pendaratan dan pelelangan ikan di pelabuhan perikanan karena lokasi pelabuhan perikanan yang jauh dengan tempat konsentrasi nelayan. Nelayan lebih suka mendaratkan ikan di tempat yang dekat dengan pemukimannya (Ruswandi dan Gartika 2013). Keterikatan modal antara nelayan dengan pedagang pengumpul juga membuat pelelangan ikan di pelabuhan perikanan tidak berjalan, karena nelayan menjual ikan langsung kepada pedagang pengumpul. Keterikatan modal membuat nelayan harus menjual ikan kepada pedagang pengumpul sebagai pemberi modal (Firdaus \& Shafitri 2013).

Berdasarkan hasil perhitungan pada Tabel 3 diperoleh nilai ketercapaian kriteria operasional pelabuhan perikanan pada Gambar 1. Tingkat pencapaian kriteria infrastruktur pendukung memperoleh nilai tertinggi yaitu $39 \%$, sedangkan kriteria fasilitas merupakan yang paling rendah yaitu $21 \%$. 
Kondisi fasilitas pelabuhan perikanan pada PPP Kota Agung sebenarnya sudah cukup baik, namun kondisi fasilitas pada enam PPI lainnya masih sangat terbatas. Fasilitas yang tersedia dengan kondisi cukup baik di enam PPI lainnya yaitu tempat pelelangan ikan (TPI) dan kantor TPI. Hal ini sesuai dengan penelitian Ikasari (2017) pada 76 PPI di Jawa Barat yang menyebutkan bahwa pemenuhan fasilitas minimal yang harus tersedia di pelabuhan perikanan mayoritas belum terpenuhi.

Berdasarkan Tabel 4 diketahui bahwa Pelabuhan Perikanan Guring memperoleh nilai kesenjangan tertinggi dengan nilai $91 \%$, sedangkan PPP Kota Agung memperoleh nilai kesenjangan terendah dengan nilai $35 \%$. Ratarata nilai kesenjangan pelabuhan perikanan adalah $73 \%$ yang berarti bahwa tingkat kesenjangan kinerja operasional pelabuhan perikanan di Kabupaten Tanggamus relatif tinggi. Dengan demikian, kondisi operasional pelabuhan perikanan di Kabupaten Tanggamus masih jauh dari kondisi standar yang diharapkan oleh pemerintah daerah. Tingkat kesenjangan yang tinggi menunjukkan kondisi operasional pelabuhan perikanan yang buruk (Irham et al. 2020).

Tabel 3 Nilai kinerja operasional pelabuhan perikanan di Kabupaten Tanggamus tahun 2020

\begin{tabular}{|c|c|c|c|c|c|c|c|c|}
\hline \multirow{3}{*}{ Pelabuhan Perikanan (PP) } & \multicolumn{6}{|c|}{ Nilai Kinerja Menurut Kriteria } & \multirow{3}{*}{$\begin{array}{l}\text { Total } \\
\text { Nilai } \\
\text { Kinerja } \\
(\%)\end{array}$} & \multirow{3}{*}{ Predikat } \\
\hline & \multicolumn{2}{|c|}{ Operasional } & \multicolumn{2}{|c|}{ Fasilitas } & \multicolumn{2}{|c|}{$\begin{array}{l}\text { Infrastruktur } \\
\text { Pendukung }\end{array}$} & & \\
\hline & $\begin{array}{l}\text { Nk } \\
(\%)\end{array}$ & $\begin{array}{l}\mathrm{Tp} \\
(\%)\end{array}$ & $\begin{array}{l}\text { Nk } \\
(\%)\end{array}$ & $\begin{array}{l}\mathrm{Tp} \\
(\%)\end{array}$ & $\begin{array}{l}\mathrm{Nk} \\
(\%)\end{array}$ & $\begin{array}{l}\mathrm{Tp} \\
(\%)\end{array}$ & & \\
\hline PPP Kota Agung & 26 & 58 & 19 & 53 & 20 & 100 & 65 & $\mathrm{~B}$ \\
\hline PPI Guring & 2 & 5 & 2 & 4 & 5 & 25 & 9 & SK \\
\hline PPI Karanganyar & 3 & 7 & 6 & 16 & 5 & 25 & 14 & SK \\
\hline PPI Tegineneng & 18 & 40 & 7 & 19 & 8 & 38 & 32 & $\mathrm{~K}$ \\
\hline PPI Badak & 17 & 38 & 5 & 14 & 8 & 38 & 30 & $\mathrm{~K}$ \\
\hline PPI Putih Doh & 3 & 7 & 6 & 18 & 8 & 38 & 17 & SK \\
\hline PPI Penyandingan & 16 & 35 & 7 & 19 & 3 & 13 & 25 & $\mathrm{~K}$ \\
\hline Rata-rata & 12 & 27 & 7 & 21 & 8 & 39 & 27 & $\mathrm{~K}$ \\
\hline Nilai Maksimal & 45 & 100 & 35 & 100 & 20 & 100 & 100 & \\
\hline
\end{tabular}

Keterangan: $\mathrm{Nk}=$ Nilai kriteria, $\mathrm{Tp}=$ Tingkat pencapaian, $\mathrm{B}=\mathrm{Baik}, \mathrm{K}=$ Kurang, $\mathrm{SK}=$ Sangat kurang.

Sumber: data primer (2020)

Tabel 4 Nilai kesenjangan operasional pelabuhan perikanan di Kabupaten Tanggamus tahun 2020

\begin{tabular}{|c|c|c|c|c|c|c|c|}
\hline \multirow{3}{*}{ Pelabuhan Perikanan } & \multicolumn{6}{|c|}{ Nilai Kesenjangan Menurut Kriteria } & \multirow{3}{*}{$\begin{array}{l}\text { Total Nilai } \\
\text { Kesenjangan } \\
(\%)\end{array}$} \\
\hline & \multicolumn{2}{|c|}{ Operasional } & \multicolumn{2}{|c|}{ Fasilitas } & \multicolumn{2}{|c|}{$\begin{array}{l}\text { Infrastruktur } \\
\text { Pendukung }\end{array}$} & \\
\hline & $\mathrm{Ng}(\%)$ & $\operatorname{Tg}(\%)$ & $\mathrm{Ng}(\%)$ & $\operatorname{Tg}(\%)$ & $\mathrm{Ng}(\%)$ & $\operatorname{Tg}(\%)$ & \\
\hline PPP Kota Agung & 19 & 42 & 17 & 47 & 0 & 0 & 35 \\
\hline PPI Guring & 43 & 95 & 34 & 96 & 15 & 75 & 91 \\
\hline PPI Karanganyar & 42 & 93 & 29 & 84 & 15 & 75 & 86 \\
\hline PPI Tegineneng & 27 & 60 & 28 & 81 & 13 & 63 & 68 \\
\hline PPI Badak & 28 & 62 & 30 & 86 & 13 & 63 & 70 \\
\hline PPI Putih Doh & 42 & 93 & 29 & 82 & 13 & 63 & 83 \\
\hline PPI Penyandingan & 29 & 65 & 29 & 81 & 18 & 88 & 73 \\
\hline Rata-rata & 33 & 73 & 28 & 79 & 12 & 61 & 73 \\
\hline Nilai maksimal & 45 & 100 & 35 & 100 & 20 & 100 & 100 \\
\hline
\end{tabular}

Keterangan: $\mathrm{Ng}=$ Nilai kesenjangan, $\mathrm{Tg}=$ Tingkat kesenjangan.

Sumber: data primer (2020) 


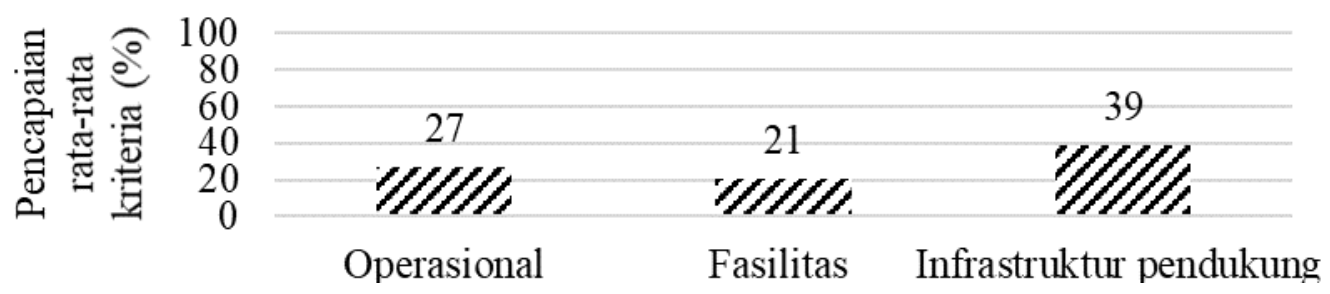

Gambar 1 Nilai ketercapaian kriteria operasional, fasilitas, dan infrastruktur pendukung pelabuhan perikanan di Kabupaten Tanggamus tahun 2020

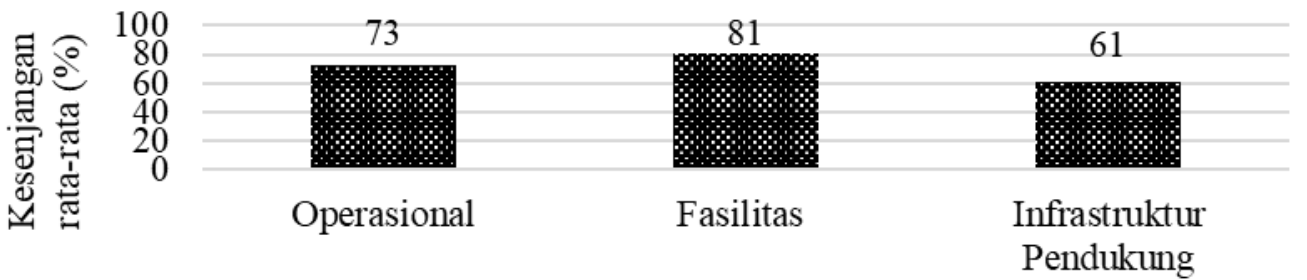

Gambar 2 Nilai kesenjangan kriteria operasional pelabuhan perikanan di Kabupaten Tanggamus tahun 2020

Berdasarkan hasil perhitungan pada Tabel 4, diperoleh nilai kesenjangan rata-rata menurut kriteria operasional, fasilitas, dan infrastruktur pendukung yang disajikan pada Gambar 2. Hasil penelitian menunjukkan kriteria infrastruktur pendukung memiliki nilai rata-rata kesenjangan terendah yaitu sebesar $61 \%$, sedangkan kriteria fasilitas memiliki nilai rata-rata kesenjangan tertinggi yaitu $81 \%$. Dengan demikian, kriteria fasilitas merupakan kriteria dengan kesenjangan tertinggi dibanding kriteria operasional dan infrastruktur pendukung. Nilai kesenjangan menunjukkan bahwa kondisi aktual pelabuhan perikanan di Kabupaten Tanggamus masih jauh dari kondisi standar yang diharapkan oleh pemerintah daerah terutama pada kriteria fasilitas pelabuhan perikanan. Hal ini dibuktikan dari hasil wawancara dengan pihak pengelola pelabuhan perikanan bahwa kondisi fasilitas pelabuhan perikanan pada kelas PPP relatif cukup lengkap, akan tetapi untuk kelas PPI yang berjumlah 6 unit masih terbatas pada lahan, TPI, kantor TPI, MCK, dan instalasi listrik.

Berdasarkan hasil penilaian kondisi operasional pada Tabel 3 dan Tabel 4, diketahui bahwa terdapat tiga pelabuhan perikanan yang tidak layak untuk dikembangkan yaitu PPI Guring, PPI Karanganyar, dan PPI Penyandingan dengan kinerja operasional yang sangat kurang dan tingkat kesenjangan yang sangat tinggi. Kondisi ini ditegaskan dengan hasil wawancara kepada pengelola pelabuhan perikanan bahwa ketiga PPI tersebut sudah tidak operasional. Pengembangan pelabuhan perikanan dapat difokuskan pada empat pelabuhan perikanan lainnya. Berdasarkan nilai pencapaian kriteria (Gambar 1) dan tingkat kesenjangan kriteria (Gambar 2), diketahui bahwa kriteria fasilitas adalah yang paling buruk dibanding kriteria operasional dan infrastruktur pendukung, sehingga perlu dilakukan penyediaan dan perbaikan fasilitas pelabuhan perikanan terutama pada pelabuhan perikanan kelas PPI.

\section{PEMBAHASAN}

Pelabuhan perikanan sebagai basis utama pada sektor perikanan tangkap di perairan Teluk Semangka Kabupaten Tanggamus dirasa belum memiliki kinerja yang baik dalam mendukung pertumbuhan ekonomi wilayah. Hasil penelitian menunjukkan bahwa hanya satu dari tujuh pelabuhan perikanan di Kabupaten Tanggamus yang memiliki kinerja operasional yang baik yaitu PPP Kota Agung, sedangkan enam PPI lainnya memiliki kinerja operasional yang kurang hingga sangat kurang.

Kinerja operasional yang baik di PPP Kota Agung dibuktikan dengan pencapaian kriteria operasional yaitu kunjungan kapal sebanyak 9 unit/hari atau $270 \mathrm{kapal} /$ bulan dari 181 unit kapal yang tercatat di PPP Kota Agung pada tahun 2020. Jumlah tersebut telah memenuhi harapan dari pemerintah daerah yang menargetkan jumlah kunjungan sebanyak 50 unit/bulan. Target yang belum tercapai adalah jumlah produksi ikan hasil tangkapan yang hanya berjumlah 1,1 ton/hari 
dari target yaitu 5 ton/hari. Hasil wawancara dengan pihak pengelola PPP Kota Agung menunjukkan bahwa produksi ikan yang tercatat di PPP Kota Agung saat penelitian hanyalah produksi ikan yang dilelang, sedangkan produksi ikan yang tidak dilelang belum tercatat. Diperkirakan jumlah produksi total ikan di PPP Kota Agung dapat mencapai dua kali lipat dari produksi ikan yang dilelang. Penyebab nelayan tidak melakukan lelang adalah adanya hubungan yang bersifat patron-client antara langgan atau pedagang ikan sebagai pemilik modal dengan nelayan sebagai peminjam modal, sehingga nelayan memiliki kewajiban untuk menjual ikan kepada langgan-nya (Sudiyono 2015; Solihin et al. 2016). Adanya hubungan antara nelayan dengan langgan tentu merugikan bagi pihak pelabuhan perikanan, karena pelabuhan perikanan khususnya TPI akan kehilangan retribusi dari ikan yang tidak dilelang yang jumlahnya diperkirakan sama dengan hasil retribusi lelang tahun 2020 yaitu sebesar $R p$. 190.629.000. Pencapaian kriteria fasilitas pelabuhan perikanan di Kota Agung sudah cukup baik dengan tersedianya fasilitas pokok, fungsional, dan penunjang yang cukup lengkap dan memadai. Kriteria infrastruktur pendukung yang tersedia di PPP Kota Agung sudah sangat memadai. Kondisi ini dipengaruhi oleh lokasi PPP Kota Agung yang berada di pusat pertumbuhan wilayah yaitu lbukota Kabupaten Tanggamus dan berada pada jalur lintas barat Sumatera sehingga kondisi infrastruktur relatif baik. Kondisi yang sama juga ditemukan di PPN Kejawan yang berada di pinggir Kota Cirebon dan berada pada jalur Pantura, sehingga infrastruktur pendukung pelabuhan perikanan relatif baik (Ruswandi \& Gartika 2013).

Tiga dari tujuh pelabuhan perikanan di Kabupaten Tanggamus yang tidak beroperasi yaitu PPI Guring, PPI Karanganyar, dan PPI Putih Doh dengan nilai kinerja yang sangat kurang dan kesenjangan yang sangat tinggi. Faktor yang menyebabkan ketiga pelabuhan perikanan tersebut tidak operasional adalah tidak adanya kegiatan pendaratan dan pelelangan ikan di pelabuhan perikanan. Ikan hasil tangkapan didistribusikan dari nelayan ke pedagang pengecer kemudian ke konsumen tanpa dilakukan lelang di pelabuhan perikanan. Pola pendistribusian seperti ini terjadi juga di PPN Karangantu, PPN Pekalongan, PPP Bajomulyo, dan PPI Bulu (Gumilang et al. 2016). Tidak hanya pelelangan ikan, tetapi pendaratan ikan juga tidak dilakukan di ketiga pelabuhan tersebut.
Tidak tersedianya fasilitas pendaratan seperti dermaga dan kolam pelabuhan serta lokasi pelabuhan perikanan yang jauh dengan pemukiman membuat nelayan lebih memilih mendaratkan ikan di dekat pemukiman dan menjual ikan langsung ke pedagang. Ditambah dengan adanya keterikatan modal antara nelayan dengan pemilik modal yaitu pedagang ikan, membuat nelayan harus menjual ikan ke pedagang ikan. Sesuai dengan Muninggar et al. (2013) yang menyatakan bahwa keterikatan modal merupakan faktor ketiga setelah harga ikan dan waktu lelang yang mempengaruhi keputusan nelayan untuk menjual ikan di luar TPI Lempasing. Ketergantungan nelayan terhadap pemilik modal disebabkan oleh kegiatan perikanan yang penuh resiko dan ketidakpastian (Fargomeli 2014). Dengan tidak operasionalnya PPI Guring, PPI Karanganyar, dan PPI Putih Doh serta kondisi fasilitas dan infrastruktur pendukung yang juga kurang memadai, dapat dikatakan bahwa ketiga PPI tidak layak untuk dikembangkan. Dengan demikian pemerintah dapat memfokuskan pengembangan pada empat pelabuhan perikanan lainnya yang sudah operasional.

Kriteria fasilitas pelabuhan perikanan merupakan kriteria dengan kesenjangan tertinggi. Kesenjangan fasilitas di pelabuhan perikanan disebabkan oleh ketersediaan dan kondisi fasilitas yang belum memadai. Fasilitas yang belum tersedia di PPP Kota Agung yaitu docking dan bengkel. Kondisi fasilitas yang belum memadai di PPP Kota Agung adalah jalan komplek, drainase, lahan parkir, breakwater, dan peralatan pemasaran, dan sumber air bersih. Fasilitas yang belum tersedia di enam PPI lainnya meliputi breakwater, dermaga, kolam pelabuhan, jalan komplek, drainase, lapak pedagang, peralatan pemasaran, SPBN mini, gerbang masuk pelabuhan, pos jaga, kantor pelabuhan, lahan parkir, dan kantin. Kondisi fasilitas yang belum memadai pada PPI adalah lahan, tempat penjemuran dan perbaikan alat tangkap, MCK, sumber air dan listrik. PERMEN KP Nomor 8 Tahun 2012 tentang Kepelabuhanan Perikanan diketahui bahwa setiap pelabuhan perikanan wajib memiliki fasilitas seperti lahan, dermaga, kolam pelabuhan, jalan komplek, drainase, kantor administrasi, TPI, sumber air bersih, sumber listrik, pos jaga, dan MCK (KKP 2012). Pelabuhan perikanan yang telah memenuhi fasilitas minimal berdasarkan PERMEN KP Nomor 8 Tahun 2012 tentang 
Kepelabuhanan Perikanan adalah PPP Kota Agung, sedangkan pada enam PPI lainnya belum memenuhi kriteria fasilitas minimal tersebut. Oleh karena itu, diperlukan upaya penyediaan fasilitas di pelabuhan perikanan Kabupaten Tanggamus guna meningkatkan pelayanan dan operasional pelabuhan perikanan. Ketersediaan fasilitas yang memadai akan meningkatkan kinerja operasional pelabuhan perikanan (Rahmayanti 2018; Santoso et al. 2018).

\section{KESIMPULAN}

Kinerja operasional pelabuhan perikanan di Kabupaten Tanggamus berdasarkan penilaian terhadap tingkat kinerja operasional dan kesenjangan pelabuhan perikanan tergolong kurang baik dengan nilai kinerja operasional yang rendah dan tingkat kesenjangan yang relatif tinggi. Terdapat tiga pelabuhan perikanan yang tidak operasional yaitu PPI Guring, PPI Karanganyar, dan PPI Putih Doh, sehingga ketiga PPI tersebut tidak layak untuk dikembangkan. Dengan demikian, pengembangan pelabuhan perikanan dapat difokuskan pada empat pelabuhan perikanan yang telah operasional yaitu PPP Kota Agung, PPI Tegineneng, PPI Badak, dan PPI Penyandingan.

\section{SARAN}

Pihak pemerintah daerah dapat memfokuskan upaya pengembangan pelabuhan perikanan pada empat pelabuhan perikanan yang operasional yaitu PPP Kota Agung, PPI Tegineneng, PPI Badak, dan PPI Penyandingan. Diperlukan upaya penyediaan dan perbaikan fasilitas pelabuhan perikanan seperti pada PPP Kota Agung yaitu pembangunan fasilitas docking dan bengkel, perbaikan pada fasilitas jalan kompleks, drainase, lahan parkir, breakwater, peralatan pemasaran dan peningkatan kapasitas sumber air bersih. Upaya pengembangan fasilitas pada PPI meliputi pembangunan breakwater, dermaga, kolam pelabuhan, jalan komplek, drainase, lapak pedagang, peralatan pemasaran, SPBN mini, gerbang masuk pelabuhan, pos jaga, kantor pelabuhan, lahan parkir, kantin, dan perbaikan fasilitas yaitu tempat penjemuran alat tangkap, MCK, serta perluasan lahan, sumber air bersih dan listrik.

\section{UCAPAN TERIMA KASIH}

Ucapan terima kasih dan penghargaan diberikan kepada Dinas Kelautan dan Perikanan Provinsi Lampung, Dinas Kelautan dan Perikanan Kabupaten Tanggamus, Pengelola Pelabuhan Perikanan di Kabupaten Tanggamus yang telah memberikan banyak informasi dalam penelitian ini.

\section{DAFTAR PUSTAKA}

[DJPT] Direktorat Jenderal Perikanan Tangkap. 2015. Keputusan Direktur Jenderal Perikanan Tangkap Nomor 20/KEP-DJPT/2015 Tentang Pedoman Evaluasi Kinerja Pelabuhan Perikanan. Kementerian Kelautan dan Perikanan Republik Indonesia.

[DJPT] Direktorat Jenderal Perikanan Tangkap. 2020. Keputusan Direktur Jenderal Perikanan Tangkap Nomor 28/KEP-DJPT/2020 Tentang Kuota Sumber Daya Ikan dan Kuota Usaha Penangkapan Ikan di Wilayah Pengelolaan Perikanan Negara Republik Indonesia 572.

Fargomeli F. 2014. Interaksi Kelompok Nelayan Dalam Meningkatkan Taraf Hidup di Desa Tewil Kecamatan Sangaji Kabupaten Maba Halmahera Timur. Journal Acta Diurna. 3(3).1-17 https://ejournal.unsrat.ac.id/index.php/ actadiurna komunikasi/article/download/5728/526 0

Firdaus M, Shafitri N. 2013. Pola Hubungan Kerja Nelayan Perairan Umum Daratan (Studi Kasus di Desa Berkat, Kecamatan Sirah Pulau Padang). Jurnal Kebijakan Sosial Ekonomi Kelautan dan Perikanan. 3(2): 143-151. http://dx.doi.org/10. 15578/jksekp.v3i2.319

Gumilang AP, Solihin I, Wisudo SH. 2016. Pola Distribusi dan Teknologi Pengelolaan Hasil Tangkapan Pelabuhan Perikanan di Wilayah Pantura Jawa. Jurnal Teknologi Perikanan dan Kelautan. 7(1): 67-76. https://doi.org/ 10.24319/jtpk.7.67-76

Guswanto B, Gumilar I, Hamdani H. 2012. Analisis Indeks Kinerja Pengelola dan Indeks Kepuasan Pengguna di 
Pelabuhan Perikanan Samudera Nizam Zachman Jakarta. Jurnal Perikanan dan Kelautan. 3(4): 151-163. http://jurnal.unpad.ac.

id/jpk/article/view/2557/2315

Ikasari AC. 2017. Konsep Kebijakan Alih Kelola Pelabuhan Perikanan di Jawa Barat. Jurnal IImiah Magister IImu Administrasi. 11(2): 44-55. https://jurnal.unnur.ac.id/index.php/jimi a/article/view/31

Irham, Iksan KH, Hardin. 2020. Evaluasi Fasilitas Fungsional Pelabuhan Perikanan Pantai Bacan. Jurnal IImu Kelautan Kepulauan. 3(2): 238-248. http://ejournal.unkhair.ac.id/index.php/ kelautan

[KEMENSETNEG] Kementerian Sekretariat Negara Republik Indonesia. 2014. Undang-Undang Republik Indonesia Nomor 23 Tahun 2014 Tentang Pemerintahan Daerah. https://peraturan.bpk.go.id/Home/Detai Is/38685/uu-no-23-tahun-2014

[KEMENSETNEG] Kementerian Sekretariat Negara Republik Indonesia. 2021. Peraturan Pemerintah Republik Indonesia Nomor 27 Tahun 2021 Tentang Penyelenggaraan Bidang Kelautan dan Perikanan. https://peraturan.bpk.go.id/ Home/Details/161858/pp-no-27-tahun2021

[KKP] Kementerian Kelautan dan Perikanan. 2012. Peraturan Menteri Kelautan dan Perikanan RI Nomor PER.08/MEN/2012 Tentang Kepelabuhanan Perikanan. http://jdih.kkp.go.id/peraturan/per-08men-2012.pdf

Kristiyanti M, Purwantini S, Wahyudi S. 2020. Pengembangan Pelabuhan Perikanan Pantai Dalam Menunjang Kegiatan Ekonomi Masyarakat Nelayan Kabupaten Batang. Jurnal Saintek Maritim. 21(1): 57-62. http://43.229.21.51/ index.php/JSTM/article/view/262/1471 47219

Lubis E. 2011. Kajian Peran Strategis Pelabuhan Perikanan Terhadap Pengembangan Perikanan Laut. $\begin{array}{lll}\text { Akuatik. } & \text { 5(2): } & \text { 1-7. }\end{array}$ https://journal.ubb.ac.id/

index.php/akuatik /article/view/430

Muninggar R, Dinarwan D, Anggara C. 2013. Faktor yang Mempengaruhi Nelayan Menjual Hasil Tangkapan di Luar TPI Lempasing: Sebuah Tinjauan Kebijakan. Buletin PSP. 21(2): 149156.

https://journal.ipb.ac.id/index.php/bulps p/article /download/25286/16457

Ngamel YA, Lubis E, Pane AB, Solihin I. 2017. Kinerja Operasional Pelabuhan Perikanan Nusantara Tual. Jurnal Teknologi Perikanan dan Kelautan. 4(2): 155-172. https://doi.org/10.24319/jtpk.4.155-172

Nugroho T, Solihin I., Fathurohim. 2012. Faktor-Faktor Penentu Kinerja Pelabuhan Perikanan Pantai (PPP) Dadap Di Kabupaten Indramayu. Marine Fisheries. 3(1): 91-101. https://doi.org/10.29244/jmf.3.1.91-101

Nurhalimah, Marwanti S, Irianto H. 2017. Analisis Dampak Pembangunan Pelabuhan Perikanan Pantai di Tamperan Kecamatan Pacitan Kabupaten Pacitan Terhadap Kondisi Sosial Ekonomi Masyarakat Sekitar. Agrista. 5(1): 191-203. https://jurnal.uns.ac.id/agrista/article/d ownload/30982/20664

Pramoda R, Zulham A, Sari YD. 2013. Kebijakan Penetapan Pelabuhan Perikanan Samudera (PPS) Bitung sebagai Kawasan Inti Minapolitan. Jurnal Borneo Administrator. 9(1): 3352. https://doi.org/10.24258/jba.v9i1.97

Rahmayanti, AZ. 2018. Peran Pemerintah dan Swasta Dalam Penyediaan Infrastruktur Perikanan Tangkap: Studi Kasus Bitung. Jurnal Ekonomi Dan Pembangunan. 26(2): 131-141. https://doi.org/10.14203/JEP.26.2.201 $\underline{8.131-141}$

Rizayani M, Chaliluddin, Rahmah A. 2016. Kajian Pelayanan Unit Pelaksana Teknis Daerah Pelabuhan Perikanan Pantai Lampulo Terhadap Kepuasan Nelayan. Jurnal IImiah Mahasiswa Kelautan dan Perikanan Unsyiah. 1(3): 448-455.

https://doi.org/10.4135/978184920940 3.n73 
Ruswandi A, Gartika D. 2013. Strategi Pengembangan Investasi di Sekitar Pelabuhan Perikanan Tipe B di Jawa Barat. Jurnal Aktuaria. 4(1): 89-101. http://jurnal.unpad.ac.id/akuatika/

Santoso H, Hamel S, Manohas J, Arifi MZ. 2018. Strategi Pengembangan Pelabuhan Perikanan Dagho. Jurnal Sains Dan Teknologi, Universitas Negeri Manado. 1(3): 283-294. https://doi.org/10.36412/frontiers/0010 35e1/desember 201801.06

Sari M, Syafrial, Efani A. 2018. Analisis Komoditas Unggulan dan Kontribusi Perikanan Tangkap Terhadap Pendapatan Asli Daerah (PAD) Kabupaten Trenggalek (Studi Kasus di Pelabuhan Perikanan Nusantara (PNN) Kabupaten Trenggalek). Berkala Perikanan Terubuk. 46(1): 78-86. https://terubuk.

ejournal.unri.ac.id/index.php/ JT/article/download/5957/5493

Siswoyo B, Kurniawan A. 2014. Pengembangan Fasilitas Penunjang Keselamatan Pelayaran di Pelabuhan Biak. Jurnal Penelitian Transportasi Laut. 16(2): 51-60. https://ojs.balitbanghub.dephub.go.id/i ndex.php/jurnallaut/article/download/4 $0 / 17$

Solihin A, Alamin MA, Isdahartatie. 2016. Penguatan Kelembagaan TPI Dalam Mewujudkan Perikanan Berkelanjutan dan Berkeadilan. Risalah Kebijakan Pertanian dan Lingkungan: Rumusan Kajian Strategis Bidang Pertanian dan Lingkungan. 3(3): 205-215. https://doi.org/10.20957/jkebijakan.v3i 3.16253

Solihin I, Wisudo S, Haluan J, Martianto D.
2011. Pengembangan Produksi Perikanan Tangkap di Wilayah Perbatasan (Kasus Kabupaten Nunukan Kalimantan Timur. Buletin PSP. 19(2): 9-18. https://journal.ipb.ac.id/index. php/bulpsp/article/view/4180

Sudiyono. 2015. Strategi bertahan hidup nelayan Pulau Rimau Balak di Kabupaten Lampung Selatan. Jurnal Bina Praja. 7(3): 211-226. https://doi.org/10.21787/jbp. 07.2015.211-225

Suman A, Irianto HE, Satria F, Amri K. 2016. Potensi dan Tingkat Pemanfaatan Sumber Daya Ikan di Wilayah Pengelolaan Perikanan Negara Republik Indonesia (WPP NRI) Tahun 2015 Serta Opsi Pengelolaannya. Jurnal Kebijakan Perikanan Indonesia. 8(2): 97-100. https://doi.org/http://dx.doi.org/10.1557 8/ jkpi.8.2.2016.97-100

Susanto A, Hamzah A, Irnawati R, Nurdin HS, Supadminingsih N. 2020. Ketahanan Pangan Perikanan di Provinsi Banten. LEUIT Journal of Local Food Security. 1(1): $\quad 9-17$. http://dx.doi.org/10.37818/leuit.v1i1.69 00

[UPTD] Unit Pelaksana Teknis Daerah Pelabuhan Perikanan Pantai Kota Agung. Laporan statistik Pelabuhan Perikanan Pantai Kota Agung tahun 2020

Wijayanto MA, Suherman A, M Kohar A. 2010. Analisis Kinerja Program Pelabuhan Perikanan Nusantara Pekalongan. Jurnal Saintek Perikanan. 5(2): 14-18. https://doi.org/https://doi.org/10.14710/ ijfst.5.2.14-18 